\title{
O que significa "Opinião Pública"? Um estudo sobre os diferentes sentidos do termo nos editoriais do jornal O Estado de S. Paulo
}

\author{
Francisco Paulo Jamil Marques, Camila Mont'Alverne, Andressa Butture Kniess \& \\ Amanda Pupor \\ Universidade Federal do Paraná \\ E-mail: marquesjamil@gmail . com / camilapessoa31@gmail . com / \\ andressakniess@gmail.com/mandapupo@gmail.com
}

\begin{abstract}
Após reconhecer diferentes abordagens teóricas conferidas ao termo "opinião pública" ao longo do século XX, o artigo examina de que maneira os editoriais do jornal $O$ Estado de $S$. Paulo (OESP) mobilizam o conceito em questão. A ideia é investigar de que maneira a "opinião pública" pode ser invocada para legitimar posições de agentes privados. Propõem-se como hipóteses: H1) O tema predominante nos editoriais analisados é Política, tendo em vista que os editoriais tendem a se dirigir às elites politicas do país. H2) A ideia de opinião pública mais recorrente nos editoriais é o sentido do termo enquanto agente ativo. São examinados quantitativamente e

qualitativamente (Análise de Conteúdo para verificar os sentidos acionados pelas peças) 95 textos editoriais publicados em OESP que, entre janeiro de 2015 e dezembro de 2016, mencionaram "opinião pública". Aponta-se que o jornal tende a mobilizar a ideia de opinião pública com maior frequência para tratar de temas relativos à política, tomando o termo, na maioria das vezes, na condição de agente ativo e autônomo para julgar os acontecimentos. O trabalho, assim, examina os modos de instrumentalização do conceito de opinião pública por parte de agentes midiáticos interessados em influenciar o debate abrigado na esfera pública.
\end{abstract}

Palavras-chave: jornalismo político; editorial; opinião pública; análise de conteúdo.

\section{What does "public opinion"mean? A study on the different meanings of the term in the editorials of the newspaper O Estado de S. Paulo}

\begin{abstract}
After recognizing different approaches to the term "public opinion"throughout the twentieth century, the article examines how the editorials of the news-

cept at stake. Based on the premise that editorials highlight the role of newspapers as political agents, it is essential to investigate whether, and how, "pupaper O Estado de S. Paulo (OESP) mobilize the conblic opinion"is evoked, for example, to legitimate
\end{abstract}

Data de submissão: 2017-06-27. Data de aprovação: 2017-12-04.

A Revista Estudos em Comunicação é financiada por Fundos FEDER através do Programa Operacional Factores de Competitividade - COMPETE e por Fundos Nacionais através da FCT - Fundação para a Ciência e a Tecnologia no âmbito do projeto Comunicação, Filosofia e Humanidades (LabCom.IFP) UID/CCI/00661/2013.
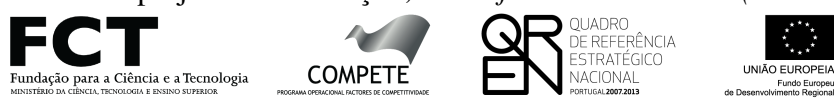

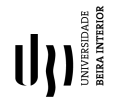


positions of private agents. We examine quantitatively (verifying the frequency with which the term is used) and qualitatively (Content Analysis dedicated to verify the senses triggered by the pieces when they refer to the term) 95 editorial texts published in OESP that, between January of 2015 and December of 2016, mentioned "public opinion". We propose the following hypotheses: H1) The main issue in the editorials in our sample is politics, once editorials tend to address the political elites. H2) The most recurrent meaning of public opinion in editorials is the use of the term as an active agent presumibly able to represent the collective will. The findings point out that the newspaper tends to mobilize the idea of public opinion more often to deal with political issues, often making it an active and autonomous agent.

Keywords: political journalism; editorial; public opinion; content analysis.

\section{Introdução}

objetivo do trabalho é examinar de que forma os editoriais do jornal $O$ Estado de $S$. Paulo (OESP) mobilizam a ideia de "opinião pública". Partindo-se da premissa de que (1) os editoriais jornalísticos evidenciam o papel dos periódicos enquanto agentes dotados de interesses e de que (2) o termo em questão compreende diferentes interpretações na Teoria Social contemporânea, mostra-se fundamental investigar se, e de que maneira, a "opinião pública" é evocada, por exemplo, para legitimar posições que, na verdade, são típicas de agentes privados.

Sabe-se, de antemão, que o termo "opinião pública" pode ser utilizado e aplicado em diferentes contextos e disputas. Tais variações de atributos conferidas a essa expressão, conforme explica Gomes (2001), surgem de batalhas ideológicas preocupadas, por exemplo, em tornar hegemônica uma compreensão específica acerca da natureza do que significa a própria noção de democracia. Em outras palavras, se as democracias representativas implicam manifestação por parte dos mandantes (seja por meio do voto, seja por meio do apoio prestado ao longo dos mandatos eletivos), o estudo dos modos de compreensão e de acionamento da opinião pública colabora para esclarecer quais atores e argumentos detêm lugar proeminente no debate público.

No caso específico deste artigo, o termo foi escolhido não somente devido às variantes teóricas que enceta, mas porque a própria empresa jornalística é parte interessada na formulação, difusão e adoção (por parte do público) de opiniões específicas (Capelato e Prado, 1980; Hallock, 2007; Kahn e Kenney, 2002). Em outras palavras, é essencial verificar em que medida os editoriais, na condição de elementos responsáveis por dar vazão às opiniões e às interpretações das empresas jornalísticas (Beltrão, 1980; Hallock, 2007), têm utilizado a expressão "opinião pública" - sobretudo em meio a períodos políticos turbulentos no cenário brasileiro recente. Assim sendo, 95 editoriais do jornal $O$ Estado de S. Paulo, publicados entre janeiro de 2015 e dezembro de 2016, e que fazem menção à "opinião pública", integram o corpus desta pesquisa.

O recorte temporal se justifica, primeiramente, por compreender o intervalo que vai da posse da ex-presidente Dilma Rousseff (PT) em seu segundo mandato - interrompido após a conclusão do processo de impeachment, em agosto de 2016 - e os primeiros meses da gestão iniciada sob responsabilidade de Michel Temer (PMDB). Destaque-se, ademais, que tal mudança no comando do Poder Executivo Federal não foi a única alteração politicamente relevante no período mencionado: o então deputado federal Eduardo Cunha (РMDB) foi afastado do cargo de presidente da 
Câmara dos Deputados (CD) em maio de 2016; a ministra Cármen Lúcia, por sua vez, assumiu a Presidência do Superior Tribunal Federal (STF) em setembro daquele mesmo ano. Todos esses acontecimentos levaram a população brasileira a acompanhar a cobertura política de maneira singular ${ }^{1}$, sobretudo por conta da continuidade das investigações conduzidas no âmbito da "Operação Lava Jato" e das manifestações que levaram às ruas grupos diversos, em diferentes cidades do país.

O estudo abrange as dimensões quantitativa e qualitativa. Assim, em um primeiro momento, a intenção é quantificar a frequência com a qual o termo "opinião pública" é utilizado nos editoriais do periódico em tela. A abordagem qualitativa, por sua vez, busca catalogar, por meio de Análise de Conteúdo, os sentidos acionados pelas peças que utilizam a expressão "opinião pública". Dada a polissemia do conceito, a intenção é compreender quais são os possíveis direcionamentos politico-ideológicos trabalhados por alguns daqueles agentes que integram e controlam parcela da chamada "esfera de visibilidade pública" (Almeida, 1999; Gomes, 2004).

$\mathrm{O}$ argumento está organizado da seguinte forma: a seção teórica se dedica a compreender as diferentes concepções da ideia de "opinião pública", o que permite diagnosticar de que maneira a comunicação de massa atuou para transformar os sentidos do termo ao longo dos últimos séculos. Tal abordagem se mostra útil, uma vez que orienta a formulação das categorias que conduzem a análise empírica. Há, também, um breve debate sobre os editoriais jornalísticos e suas funções políticas. Em seguida, apresentam-se as estratégias metodológicas empregadas pelo trabalho e procede-se com a análise do corpus empírico selecionado. Por fim, discutem-se os resultados e apontam-se as conclusões da investigação.

A contribuição do artigo se revela uma vez que sistematiza e reconhece a trajetória histórica das principais vertentes a definirem o termo "opinião pública", além de oferecer um estudo de caso no qual, objetivamente, é possível verificar os modos de instrumentalização do termo por parte de instituições interessadas em direcionar o debate abrigado no âmbito da esfera pública.

\section{Seção Teórica}

\subsection{Opinião Pública, Mídia e Democracia}

O "público" - muitas vezes também interpretado como sinônimo de esfera da cidadania (Marques, 2010; Miola, 2012) - ocupa uma função essencial nas democracias representativas, uma vez que uma parte dele se mostra responsável por atuar no processo de escolha dos representantes políticos. Conforme indicam Richards Jr. e Gastil (2015), as tentativas de influenciar a formação das preferências dos cidadãos têm sido objeto de preocupação em Teoria Política já há um par de séculos.

1. Há dados indicando que produtos jornalísticos, a exemplo do Jornal da Globo e da Folha de S. Paulo, experimentaram um aumento em sua audiência devido à cobertura sobre a crise política brasileira. Disponível em http://noticiasdatv.uol.com.br/noticia/audiencias/com-lava-jato-jornal-da-globo-bate-recorde-de-audiencia-noano-10661 e em www1.folha.uol.com.br/poder/2016/04/1756644-com-crise-politica-folha-bate-todos-os-recordes-deaudiencia-e-se-distancia-de-concorrentes.shtml. Acesso em 2 jun. 2017. 
O filósofo britânico John Stuart Mill designou um papel maior para o público em relação ao governo. A legislatura se mostraria adequada exclusivamente na condição de um fórum no qual uma ampla gama de opiniões políticas poderia ser veiculada e interrogada, para que os funcionários públicos e o público em geral pudessem descobrir o conteúdo e relativa magnitude das posições dos cidadãos e das partes sobre questões de política, bem como os pontos fortes e fracos de tais posições. Este conhecimento da opinião pública permitiria que a legislatura, então, fizesse escolhas políticas estando informadas $^{2}$ (Richards Jr. e Gastil, 2015, pp. 8).

Os media ocupam um papel especial nesse contexto, uma vez que é graças à comunicação de massa (seja na condição de instrumento, seja na condição de instituição) que a sociedade pode aceder aos acontecimentos do jogo político (Campos, 2015; Maia, 2008; Gomes, 2004; Manin, 1995; Schudson, 2008). Assim, o Jornalismo, mais exatamente, além de reivindicar legitimidade na condição de mediador do relato dos fatos, toma para si a tarefa de orientar o público, inclusive por meio da oferta de opiniões que lhes são peculiares.

Fica claro, desse modo, que as empresas jornalísticas, ao conferirem visibilidade a determinados atores do campo político, acabam por influenciar a construção da imagem - e da credibilidade - daqueles que exercem papel representativo (Cook, 2005; Hahn, Lee e Lee, 2015; Sodré, 2009; Van Dalen, 2015; Arnold, 2004).

Conforme Lippmann (2008), o sentimento que alguém cultiva acerca de determinado evento que não vivenciou está associado à imagem mental e mediada construída pelos media $^{3}$ (Maia, 2008). A comunicação de massa exerce, portanto, uma função representativa nas sociedades contemporâneas, constituindo-se como espaço privilegiado para a disseminação de perspectivas diversas e das concepções de mundo defendidas por grupos em conflito (Miguel, 2014).

A partir do momento em que o conteúdo tornado disponível pela comunicação de massa torna-se importante para indicar quais são as discussões prioritárias na agenda social (McCombs e Shaw, 1972), os media passam a, efetivamente, influenciar a formação da opinião pública seja apresentando-se como canal pelo qual as opiniões são expressas, seja reivindicando-se como representante da própria opinião pública.

Os media são um sistema intermediário - semelhante a partidos políticos ou a grupos de interesse - que reconhece e agrega as necessidades cívicas e as transforma para que possam adentrar o processo de tomada de decisões políticas. (Eberwein, Porlezza e Splendore, 2015, pp. 5).

Ao se examinar, porém, a agenda noticiosa e as opiniões públicas que circulam nos media, talvez um problema já identificado na Teoria Política moderna acabe sendo reproduzido: a pos-

2. Os trechos de trabalhos cujos originais foram publicados em língua estrangeira tiveram sua tradução providenciada pelos autores deste trabalho.

3. De acordo com o Lippmann: "Aqueles aspectos do mundo exterior que têm a ver com o comportamento de outros seres humanos, na medida em que o comportamento cruza com o nosso, que é dependente do nosso, ou que nos é interessante, podemos chamar rudemente de opinião pública. As imagens na cabeça destes seres humanos, a imagem de si próprios, dos outros, de suas necessidades, propósitos e relacionamento, são suas opiniões públicas. Aquelas imagens que são feitas por grupos de pessoas, ou por indivíduos agindo em nome dos grupos, é Opinião Pública com letras maiúsculas". (2008, p. 40) 
O que significa "Opinião Pública"? Um estudo sobre os diferentes sentidos do termo nos editoriais do jornal O Estado de S. Paulo

sibilidade de "descolamento" entre as prioridades estabelecidas, de um lado, pelos profissionais do campo político e do campo da comunicação e, de outro, a pauta de real interesse dos cidadãos (Fallows, 1997; Kovach e Rosenstiel, 2004). De acordo com Doris Graber (2003):

A visão de que os media enquadram as notícias para refletir a opinião de vários públicos ou as opiniões da maioria é outro mito que tem pouca relação com a realidade política. No entanto, tal mito tem maiores consequências uma vez que os observadores políticos muitas vezes igualam a confiança na cobertura midiática com algo próximo a uma opinião pública unânime, sendo que tal unanimidade também é um mito. A imprensa não pode funcionar como um megafone da opinião pública porque não mantém contato com as várias facções existentes do público. (Graber, 2003, pp. 145).

Tendo em vista as ponderações acima, destacam-se, como agenda de trabalho de variados autores, as tensões no que concerne ao conceito de "opinião pública" - o que acaba implicando atribuição de significados distintos ao termo. O próximo tópico dedica-se, justamente, a diagnosticar as diferentes acepções relacionadas a tal ideia, a fim de oferecer suporte teórico à análise empírica e discussão apresentadas na segunda metade do texto.

\subsection{As variantes teóricas do conceito de "opinião pública"}

O conceito de opinião pública tem sido objeto de reflexão por parte de diferentes matrizes teóricas. Conforme Donsbach (2015), trabalhos como o de Schoenbach e Becker (1995) distinguem, pelo menos, cinco definições principais do termo.

(1) Qualquer opinião sustentada por uma maioria dos cidadãos (definição quantitativa); (2) a opinião da elite, com capacidade intelectual ou poderes para influenciar a sociedade (definição normativa-elitista); (3) qualquer opinião sobre assuntos públicos (aliás, essa é a definição, por objeto, de opinião); (4) uma opinião alcançada através de um processo público de aprendizagem e de consenso (a opinião pública deliberativa); e (5) qualquer opinião a ser expressa em público, sem medo de isolamento social (definição psicossocial da opinião pública). (Donsbach, 2015, pp. 3).

Tamanha amplitude terminológica gera dificuldade em saber a qual perspectiva se faz referência quando se enuncia o conceito - principalmente se for considerado que outros sentidos não foram contemplados nas possibilidades acima elucubradas, como aquele de opinião pública enquanto agente ativo (dotado de vontades e capaz de pressionar representantes, por exemplo) ou passivo. Tal variedade interpretativa é compreensível, uma vez que a expressão em tela é formada por duas palavras polissêmicas: a noção de "público" - termo que, nas línguas inglesa e portuguesa, pode adotar tanto o caráter de adjetivo, quanto de substantivo; e a ideia de "opinião", que, paralelamente, também passou por transformações diversas (sobretudo ao longo do século $\mathrm{XX}$ ), partindo da idealização de que seria o resultado de um julgamento bem fundamentado, até alcançar o status de mera disposição a ser mensurada por sondagens, conforme indica Patrick Champagne (1996). 
Além da polissemia terminológica, a abordagem conferida ao conceito no curso do tempo acabou implicando sentidos distintos à expressão. Noelle Neumann e Petersen (2004), por exemplo, argumentam que, da Antiguidade até o século XVIII, a noção de opinião pública foi empregada no sentido de possibilitar um tipo de "controle social", possível graças à almejada conformação de um amplo consenso ao qual os indivíduos deveriam se ajustar. Depois de tal período, teria ganho projeção a ideia de opinião pública como resultado de debates fundamentados no princípio da razão (Habermas, 1984).

Tendo em vista as variantes teóricas brevemente expostas até o momento, o objetivo desta seção é elaborar, a partir de diálogo com a literatura pertinente, um mapeamento conceitual acerca das diferentes compreensões sobre "opinião pública", na esteira dos esforços anteriormente delineados por autores como Gomes (2001). Duas ponderações se mostram fundamentais a esta altura: a diferença para o trabalho de Gomes (2001), no caso ora apresentado, refere-se à intenção de construir um quadro mais amplo e atualizado sobre as principais compreensões que a referida expressão ganhou nas últimas décadas. O mapeamento se mostra útil não somente para resgatar o que referências anteriores trouxeram, mas, também, para balizar as categorias analíticas que serão trabalhadas na seção empírica do artigo.

Em segundo lugar, sublinhe-se que a discussão sobre as interpretações apresentadas logo a seguir acerca do termo "opinião pública" não têm a função de propor um histórico do conceito, retomando suas raízes filosóficas iluministas - algo que já foi contemplado, de maneira mais do que satisfatória, nos trabalhos de Matteucci (1983), Glasser e Salmon (1995), Grossi (2007) ou de Esteves (2010). Nem se pretende esgotar todas as contribuições teóricas concernentes à noção central que interessa ao artigo, tanto que o texto se refere, essencialmente, àquelas perspectivas de maior projeção ao longo do século XX. O objetivo é, antes, verificar de que maneira a comunicação de massa contribuiu para alterar as possibilidades interpretativas concernentes à ideia de opinião pública, oferecendo-se um exercício empírico que recorta uma das possibilidades de aplicação do termo.

Uma nota de cautela antes de detalhar as sete perspectivas que este trabalho diagnosticou no percurso teórico: é essencial ressaltar que, em maior ou menor medida, as diferentes acepções delineadas a seguir mantêm conexão mútua. Alguns dos itens apontados abaixo, inclusive, são tributários uns dos outros, tendo-se optado por considerá-los separadamente por se julgar haver fenômenos que justificam a proposição de uma tipologia específica.

\section{Perspectiva (1): O clássico debate entre Lippmann e Dewey sobre a ideia de “opinião pú- blica"}

No livro “Opinião Pública”, originalmente publicado em 1922, Walter Lippmann (2008) apresenta tal conceito vinculando-o à opinião compartilhada por uma coletividade, isto é, à ideia ou avaliação que as pessoas têm acerca de determinados assuntos.

Aqueles aspectos do mundo exterior que têm a ver com o comportamento de outros seres humanos, na medida em que o comportamento cruza com o nosso, que é dependente do nosso, ou que nos é interessante, podemos chamar rudemente de opinião pública. As imagens na cabeça destes seres humanos, a imagem de si próprios, dos 
O que significa "Opinião Pública"? Um estudo sobre os diferentes sentidos do termo nos editoriais do jornal O Estado de S. Paulo

outros, de suas necessidades, propósitos e relacionamento, são suas opiniões públicas. Aquelas imagens que são feitas por grupos de pessoas, ou por indivíduos agindo em nome dos grupos, é Opinião Pública com letras maiúsculas. (Lippmann, 2008, pp. 40).

Considerando-se a possibilidade de haver distorções nos modos pelos quais os indivíduos interpretam ou são levados a interpretar os fatos, Lippmann (2008) ressalta o processo de construção da opinião pública por meio do Jornalismo, que proporcionaria ao público, na visão do autor, um ambiente projetado, em detrimento da realidade concreta (Lippmann, 2008). Assim, segundo Lippmann (2008), os conteúdos jornalísticos seriam incapazes de relatar os acontecimentos de maneira desprovida de estereótipos - o que se mostraria particularmente grave, já que a comunicação de massa carrega consigo a responsabilidade de organizar o debate público.

Após a repercussão do livro de Lippmann, John Dewey (1927) também se dispôs a tratar da ideia de opinião pública, definindo-a como um "julgamento que é formado por aqueles que constituem o público e que se refere a assuntos de natureza pública". É verdade que tal afirmação de Dewey guarda alguma semelhança com o argumento de Lippmann. Porém, uma diferença relevante entre os dois autores se refere à importância conferida ao debate público.

Se Lippmann defendia a necessidade da contribuição de especialistas para a tomada de decisões de melhor qualidade (já que tal artifício contornaria os desvios causados, segundo o autor, pela comunicação de massa), Dewey apontava o "clima de controle oligárquico das informações e de manipulação de notícias, argumentando que sustentar a democracia exigiria melhorar as oportunidades de discussão pública e debate"(Sproule, 2015, p. 4). Na perspectiva de Dewey (1927), assim, a imprensa teria, normativamente, função significativa a ser desempenhada para estabelecer e consolidar democracias no século XX, não obstante ele também tecesse críticas às atividades ligadas ao campo jornalístico.

As divergências entre os dois autores também se apresentam no que concerne aos papeis que ambos autores atribuem ao público (Campos, 2015). Para Lippmann, a finalidade específica do público nas democracias seria votar no sentido de escolher os agentes autorizados a integrarem os círculos de poder. Dewey (1927) discorda dessa visão, afirmando que "nenhum governo de especialistas no qual as massas não têm a oportunidade de informar a tais especialistas acerca de suas necessidades nada mais é do que uma oligarquia gerida conforme os interesses de poucos"(Dewey, 1927, p. 207-208).

As contribuições de Lippmann e Dewey, assim, denotam preocupação, já no início do século XX, com o papel da comunicação de massa para a constituição da opinião pública, o que vai se refletir em perspectivas teóricas posteriores.

\section{Perspectiva (2): A noção habermasiana clássica de "opinião pública"}

Também no século XX, a discussão sobre a ideia de opinião pública foi marcada pelo livro "Mudança Estrutural da Esfera Pública" (lançado, originalmente, em 1962), do filósofo Jürgen Habermas. De acordo com o autor, a esfera pública - enquanto ambiente da vida social no qual a comunicação se torna visível e acessível - propiciaria a emersão do que ele passou a denominar 
de opinião pública. Em outras palavras, a opinião pública consistiria do resultado provisório da competição de discursos que têm lugar na esfera pública (Maia, 2008).

No entender de Habermas (1984), entretanto, a mediação dos debates realizada pela comunicação de massa teria alterado, para pior, a natureza da esfera pública - e, naturalmente, da opinião pública -, uma vez que, dentre outras modificações, dispensaria a necessidade de interação presencial entre os agentes envolvidos nas disputas argumentativas. Assim, os jornais, por exemplo, passaram a divulgar, a defender e a comercializar somente um conjunto específico de opiniões que não necessariamente visavam permitir o controle público das instituições do Estado, como o filósofo alega ter ocorrido outrora, mas tinham como prioridade a busca por consentimento a visões de mundo previamente e estrategicamente concebidas (Habermas, 1984).

De forma mais direta, Habermas (1984) considera que a expansão dos media, bem como o fato de os periódicos jornalísticos terem passado a se constituir como empresas que buscam lucro, ocasionariam a transformação da imprensa em "pórtico de entrada de privilegiados interesses privados na esfera pública" (Habermas, 1984, p. 218). Ao mesmo tempo, paradoxalmente, não mais seria viável abrir mão da mediação informacional oferecida pela comunicação de massa, ora detentora do controle sobre a esfera de visibilidade pública com maior capacidade de atrair atenção (Campos, 2015).

A "mudança estrutural" diagnosticada pelo pensador alemão, assim, refere-se ao fato de que tanto "esfera pública" quanto "opinião pública" agora veem aumentados os riscos de "manipulação" (Correia, 2010). Tal concepção acaba por ressaltar as características típicas de um novo quadro social e interpretativo que a comunicação de massa proporcionou de modo a afetar as interpretações pertinentes ao conceito de opinião pública, conforme será discutido a seguir.

\section{Perspectiva (3): A “opinião pública” como "opinião publicada”}

Na esteira das preocupações concernentes à formação da opinião pública e de sua relação com a comunicação de massa, abre-se a oportunidade de refletir acerca da ideia de "opinião publicada". Ao contrário da ideia de opinião pública que se apresenta como fruto das trocas argumentativas ocorridas no confronto de razões que marca a esfera pública, a opinião publicada (a qual Habermas também mencionou em sua obra clássica) nada mais seria do que aquela que se encontra exposta e disponível socialmente (Gomes, 2001). Isto é, refere-se ao caráter de circulação (e não prioritariamente de elaboração) pública da opinião nas sociedades contemporâneas.

Aqui, destaca-se, uma vez mais, o papel dos media: em vez de forjada por meio da discussão arrazoada entre diferentes agentes, a opinião pública(da) seria, de modo geral, aquela perspectiva que ganha projeção por ter sido a escolhida, dentre várias outras possíveis, por aqueles que controlam a esfera de visibilidade pública. Assim, a depender dos privilégios de visibilidade alcançados por determinados grupos, suas agendas podem ser apresentadas, sem maiores contestações, como se fossem prioritárias ou hegemônicas. Para Habermas (1984), a opinião publicada circula com o intuito central de obter adesão, fazendo com que o indivíduo se limite a escolher aquela posição que mais lhe agrada ou convém dentre o leque de opiniões disponíveis.

Também de acordo com Gomes (2001), dois agentes são importantes para a ideia de opinião publicada: os "opinadores profissionais" contratados por instituições midiáticas (jornalistas que 
O que significa "Opinião Pública"? Um estudo sobre os diferentes sentidos do termo nos editoriais do jornal O Estado de S. Paulo

têm espaço regular em artigos e colunas, por exemplo) e agentes que recebem autorização para expressar suas opiniões em espaços publicamente disponíveis e socialmente reconhecidos (é o caso de indivíduos com expertise técnica acerca de um assunto). Em outras palavras, algumas personalidades são admitidas pelos mass media como sujeitos de opinião, enquanto outros enfrentam batalhas mais árduas para ver suas posições circulando amplamente.

\section{Perspectiva (4): A relação entre "opinião pública" e "política de opinião"}

Se parte fundamental do processo de construção das imagens públicas que permeiam a política contemporânea passa pela tentativa de obter a adesão do público a determinadas opiniões, posturas, agendas, pessoas ou instituições, logo se mostrou evidente a necessidade de formular e administrar estratégias voltadas para a obtenção de consentimento - e que implicam a utilização de recursos vinculados à comunicação de massa (Hacker, 2004; Weber, 2004, 2009).

Se tal fenômeno não é recente - tanto que Lippmann (2008) tratou do caso de assessores que atuavam, desde as primeiras décadas do século XX, na área de comunicação -, deve-se admitir que a profissionalização da gestão de imagem se acentuou ao longo dos últimos anos, demandando mais verbas e mais especialistas no sentido de prover ao público insumos informacionais (enviesados ou não) que possibilitem uma "campanha permanente" (Gomes, 2004; Holtz-Bacha, 2015; Negrine, 2015; Thurber e Ray, 2015; Blumenthal, 1982).

A ideia de política de opinião, assim, compreende três atividades primordiais: "a construção da opinião; o ajuste entre a opinião que o público deseja e a opinião publicada; manter como [se fosse] opinião do público a opinião [que é, na verdade] particular" (Gomes, 2001, p. 10). Na prática, dentre os recursos mais recorrentemente utilizados pelos administradores das políticas de imagem estão desde a identificação e o monitoramento das posições políticas melhor aceitas pelo público (a fim de "sintonizar" o assessorado com as expectativas coletivas), até a contratação de jornalistas experientes - na condição de assessores de imprensa e com uma boa agenda de contatos - com o intuito de "facilitar" o trânsito de visões de mundo estrategicamente construídas.

\section{Perspectiva (5): A ideia de "opinião pública" como um "conjunto abstrato de públicos"}

De forma a contemplar o termo "público" na condição de substantivo (mais exatamente enquanto sujeito), uma outra perspectiva se refere a tal conceito enquanto instância demográfica. Ou seja, no caso, "opinião pública" seria relativa a uma espécie de "entidade" que "inclui os concernidos por uma matéria qualquer enquanto, forçosamente, são dotados de posição própria quando esta matéria está em disputa" (Gomes, 2001, p. 65). Na verdade, mesmo que parte dos cidadãos ignore o que está sendo debatido ou disputado socialmente do ponto de vista ideológico, eles acabariam sendo incluídos em um grupo que implica uma parcela dos cidadãos que, alega-se, pensariam de forma semelhante (Champagne, 1996).

Nesta concepção, a opinião pública, não obstante ser apresentada como uma posição consensual da sociedade, não é aquela aferida por instrumentos, a exemplo das sondagens. Trata-se, frequentemente, assim, de acionar o termo como parte da estratégia retórica que visa atribuir à maioria uma perspectiva de mundo que, na verdade, tem origem, muitas vezes, particularista. 
Gomes defende, assim, que, em diversas ocasiões, quando se fala em "opinião pública", o sentido efetivamente acionado pelo interlocutor se refere à população, ao público de forma geral ou, mesmo, ao "povo", ainda que de forma vaga ou imprecisa quanto à dimensão e ao papel de tal entidade: “... a expressão parece ainda estar associada ao fenômeno da opinião, na medida em que deixa de designar a opinião do público para designar o sujeito coletivo de opiniões" (Gomes, 2001, p. 5).

\section{Perspectiva (6): As sondagens de opinião e a ideia de que revelariam a "opinião pública"}

Uma estratégia recorrente para conhecer os comportamentos e as preferências dos cidadãos se refere às sondagens, que ganharam espaço nas democracias modernas, sobretudo a partir da década de 1930 (Nunes, 2000; Donsbach, 2015). Se a política de opinião perpassa a conquista da aprovação pública, conhecer os desejos e as disposições dos cidadãos constitui necessidade básica dos gestores de imagem - que investem recursos cada vez maiores para mensurar cada detalhe dos hábitos e das formas de pensar daqueles a quem desejam influenciar ${ }^{4}$.

Champagne (1996), ao discutir a importância da opinião pública no jogo político contemporâneo, cita as sondagens como fator crucial no processo de conquista de "corações e mentes". Ao apontar que as sondagens de opinião são uma ferramenta a serviço de certo número de agentes - que contratam especialistas para a formulação (enviesada ou não) de perguntas, para coleta e tabulação dos dados, bem como profissionais de marketing ou cientistas sociais que ajudam a interpretar os resultados -, o autor descortina o fato de que tais levantamentos apenas apresentam uma forma peculiar de opinião: aquela "fabricada" ou manipulável, uma vez que os modos de construção e de aplicação das questões, além dos critérios de seleção dos entrevistados, pode alterar ou induzir os resultados (Bourdieu, 1980).

Um dos problemas das sondagens, de acordo com Esteves (2010), é tomar como certo que "todo o indivíduo tem, sempre, opinião sobre tudo; todas as opiniões se equivalem; é possível, a qualquer momento, formular de modo incontroverso os termos e as questões da opinião pública" (p. 28-29). Em crítica semelhante, Noelle-Neumann (1995) argumenta que as pesquisas de opinião pública acabam conferindo o mesmo peso a opiniões individuais, desconsiderando o grau de informação que as pessoas têm acerca de um assunto. Diante disso, pesquisadores vinculados a diferentes matizes teóricas têm se mostrado receosos, dado o fato de que as sondagens teriam se tornado uma instituição dotada de autoridade social, inclusive reivindicando para si o status de objetividade científica ao lançar mão, por exemplo, de métodos de coleta por amostragem.

\section{Perspectiva (7): A espiral do silêncio e a "opinião pública" como fator que influencia na inserção social dos indivíduos}

A última perspectiva aqui debatida toma a ideia de "opinião pública" como entidade capaz de influenciar o comportamento dos indivíduos. Ao perceber e monitorar o clima de opinião ao seu

4. Sobre gastos com campanhas eleitorais no Brasil e nos Estados Unidos, ver http://politica.estadao.com. br/ noticias/geral,campanhas-gastaram-r-5-bilhoes-em-2014-imp-,1600362 e também www.washingtonpost.com/grap hics/politics/2016-election/campaign-finance/. Acesso em 05 mai. 2017. 
O que significa "Opinião Pública"? Um estudo sobre os diferentes sentidos do termo nos editoriais do jornal O Estado de S. Paulo

redor, cada pessoa controlaria o que verbalizar ou não, a depender do ambiente em que se encontra, sobretudo se estiver em sua pauta de prioridades a intenção de evitar seu próprio isolamento social ou obter consentimento coletivo (para exercer um cargo representativo, por exemplo). Tal concepção foi sistematizada por Elisabeth Noelle-Neumann (1995):

Observações realizadas em determinados contextos se espalharam para outros e incitaram as pessoas a expressar suas opiniões ou a "engoli-las"e a manterem-se em silêncio até que, em um processo de espiral, um ponto de vista passou a dominar na cena pública e o outro desapareceu da consciência pública ao emudecer seus apoiadores. Este é o processo que podemos descrever como "espiral do silêncio"(NoelleNeumann, 1995, pp. 22).

A bem da verdade, a pesquisadora alemã está interessada em compreender as razões que levam algumas opiniões a se tornarem majoritárias ou minoritárias na esfera pública. A inibição para expressar determinado ponto de vista divergente teria como efeito imediato a percepção, por parte do "intimidado", de que aquelas opiniões a receberem apoio explícito seriam mais fortes do que realmente são (Noelle-Neumann, 1995). Em outras palavras, os comportamentos dos indivíduos ao aderir ou defender publicamente uma visão de mundo específica seria influenciada pela opinião pública que ele sente ser predominante (Ho, 2015). A função dos media, nesse contexto, é primordial, visto que o Jornalismo, por exemplo, expõe e julga publicamente os limites daquilo que é ou não socialmente aceitável, sobretudo quando estão em jogo divergências e controvérsias morais (Cervi, 2006; Noelle-Neumann e Petersen, 2004).

Ressalte-se que as categorias desenhadas permitem lidar com dimensões diferentes da ideia de opinião pública. Enquanto a perspectiva "habermasiana clássica" e "resultado de sondagens" tratam opinião pública como "produto" (seja de debates, seja de mensurações empíricas), as categorias "persuasível", "agente ativo" e "agente passivo" enquadram-na na condição de agente. Tal riqueza concentual evidencia a necessidade de compreender as diferentes manifestações teóricas e empíricas concernentes à utilização do termo.

Após apresentar sete possibilidades interpretativas (algumas, complementares entre si, conforme pôde ser verificado) conferidas pela literatura ao termo "opinião púbica", realiza-se, a seguir, uma breve discussão sobre as funções e as características do editorial jornalístico. Tal debate se mostra relevante uma vez que a seção empírica se dedicará a investigar de que maneira a tomada de posição por parte dos periódicos implica o uso de diferentes sentidos do conceito de "opinião pública”.

\subsection{As funções políticas do editorial jornalístico: Uma breve reflexão}

O editorial é um gênero jornalístico singular, uma vez que expõe, de maneira clara, o posicionamento da empresa acerca de diferentes assuntos de concernência pública (Beltrão, 1980; Guerreiro Neto, 2016). De acordo com Rupar (2007), “[o] papel do editorial é idiossincrático: 
enquanto notícias informam, editoriais avaliam; onde as notícias explicam o que aconteceu, o editorial conta por que e como isto pode afetar nossas vidas" (p. 599). Justamente por consistir em um espaço no qual a instituição jornalística pode veicular suas opiniões, o estudo de textos de tal natureza permite verificar as tensões existentes entre interesses públicos e privados no ramo jornalístico (Mont'Alverne e Marques, 2015).

Por representarem a posição da elite que integra o campo midiático (Bennett, Lawrence e Livingston, 2007), mas também ao se direcionarem às demais elites políticas e econômicas (Albright, 1995; Entman, 2007; Hallock, 2007; Izadi e Saguaye-Biria, 2007), encontra-se, dentre as funções políticas dos editoriais, a comunicação daquilo que o jornal entende como correto ou apto a contemplar o interesse público. Desse modo, os editoriais também desempenham a tarefa de colaborar para a construção da opinião pública, oferecendo insumos informacionais e opinativos que serão processados por agentes sociais de naturezas e posicionamentos diversos. Se, de acordo com o que afirma Beltrão (1980), o jornal atua na condição de catalisador de opiniões, o editorial seria a expressão do "somatório do que pensa uma expressiva parcela da opinião pública, representada pelo grupo que fundou, orienta e mantém o jornal" (p. 52).

Dito de outra forma, pode-se afirmar, de maneira prática, que os editoriais podem, por exemplo, atuar enquanto opinião publicada ou como parte de uma estratégia de política de opinião. É possível constatar, ademais, que, ao reivindicar-se na condição de "representante" do interesse público, o editorial pode tanto veicular resultados de sondagens, quanto defender posições nele endereçadas como se fossem a opinião geral da esfera da cidadania. São essas diferentes possibilidades de sentido de uso da expressão "opinião pública" em editoriais - especificamente no caso de O Estado de S. Paulo (OESP) - que a seção empírica deste artigo deseja investigar. Argumenta-se que tal proposta confere a oportunidade de observar como a empresa jornalística atua como agente dotado de interesse político.

\section{Seção Metodológica}

A amostra selecionada para este trabalho foi construída a partir de um banco de dados no qual estão arquivados todos os editoriais publicados por OESP entre janeiro de 2015 e dezembro de 2016 - o total de editoriais catalogados é de 2193 peças. A coleta do material foi feita a partir das edições digitais do jornal em questão, tendo sido realizado o download dos arquivos PDF das páginas que correspondem à versão impressa nas quais os textos sob análise foram veiculados 5 .

$\mathrm{O}$ estabelecimento do recorte se deu da seguinte maneira: foram buscados os editoriais que trouxessem a palavra-chave "opinião pública" ao longo dos 24 meses acima indicados, o que resultou em um total de 95 textos publicados em 2015 e 2016. Ressalte-se que o processo de contagem e catalogação dos editoriais implicou dupla checagem, sob responsabilidade de diferentes pesquisadores que respondem pela autoria deste trabalho, a fim de ratificar a quantidade exata de unidades textuais que mencionam o termo.

O jornal OESP foi escolhido por ter como uma de suas marcas a clara tomada de posição política (Capelato e Prado, 1980; O Estado de S. Paulo, 1997; Sodré, 1999), tendo ele atuado,

5. OESP publica três editoriais por dia, na página A3, além de um editorial econômico no Caderno de Economia. Nesta pesquisa, consideraram-se apenas as peças publicadas na terceira página. 
O que significa "Opinião Pública"? Um estudo sobre os diferentes sentidos do termo nos editoriais do jornal O Estado de S. Paulo

tradicionalmente, como periódico que se dirige a elites políticas e econômicas (Guerreiro Neto, 2016; Sodré, 2009), além de ter uma das maiores tiragens entre os quality papers brasileiros ${ }^{6}$.

Duas hipóteses conduzem a análise proposta:

H1) O tema predominante nos editoriais analisados é Política, tendo em vista que os editoriais tendem a se dirigir às elites políticas do país (Azevedo, 2016; Capelato e Prado, 1980; Guerreiro Neto, 2016; Sodré, 2009).

H2) A ideia de opinião pública mais recorrente nos editoriais é o sentido do termo enquanto agente ativo, capaz de representar a vontade coletiva. A mobilização de tal sentido constitui-se como uma estratégia para o jornal apresentar suas próprias demandas com verniz de legitimidade, com intuito de demonstrar que elas são de interesse público.

Os procedimentos metodológicos empregados no trabalho estão divididos em dois momentos: o primeiro deles tem caráter quantitativo e se dedica a aferir a frequência de aparição do termo "opinião pública" no jornal ao longo dos meses examinados. Em seguida, a abordagem qualitativa se sustenta em uma Análise de Conteúdo que abrange duas dimensões: uma geral, dedicada a compreender a temática dos textos que compõem a amostra (mapeando-se os principais assuntos presentes nos editoriais que trazem o termo "opinião pública"); e outra específica, orientada a diagnosticar o sentido de opinião pública acionado pelo periódico. Para isso, seguiram-se os passos indicados pela literatura (Bardin, 1977; Bauer, 2002; Cavalcante, Calixto e Pinheiro, 2014; Krippendorff, 2004), que sugere uma pré-análise do material.

De acordo com pesquisa anterior conduzida por Mont'Alverne e Marques (2016), os temas dos editoriais de jornais a exemplo de $O$ Estado de $S$. Paulo compreendem quatro eixos principais:

1. Política: textos que fazem menção ao jogo político, às disputas partidárias, às relações entre Executivo, Legislativo e Judiciário; a escândalos de corrupção e a investigações de atos ilícitos por parte de agentes do campo político; a Comissões Parlamentares de Inquérito (CPIs), dentre outras instâncias que envolvem diretamente o Estado.

2. Economia: textos relacionados a assuntos econômicos locais, nacionais e internacionais; à situação econômica do Brasil; às medidas adotadas - ou que os periódicos sugerem que devem ser adotadas - pelos governantes e pelos congressistas; à gestão de empresas estatais.

3. Questões Sociais: textos que tratam de assuntos diretamente ligados à dinâmica social, como pobreza, segurança pública ou aprovação de novas leis que regulamentam relações trabalhistas; greves e manifestações da esfera civil e de movimentos sociais; acesso a e/ou qualidade dos serviços públicos; problemas enfrentados pelos cidadãos em seu cotidiano.

4. Outros: textos editoriais que não se enquadrem nas categorias anteriormente delineadas.

Seguindo tal proposta, cada editorial foi classificado em apenas um destes temas acima.

A segunda dimensão qualitativa se dedica à Análise de Conteúdo sobre os sentidos de "opinião pública" acionados pelo jornal OESP em seus editoriais. Nesta parte da investigação, a unidade de análise é a palavra-chave "opinião pública". Assim, ainda que o corpus seja composto por 95 peças, cada vez que o termo em questão foi mobilizado pelo texto, houve registro e classificação.

6. Disponível em www.anj.org.br/maiores-jornais-do-brasil/. Acesso em 3 mar. 2017. 
Deste modo, tem-se 105 ocorrências codificadas ${ }^{7}$. Cada uma delas foi encaixada em apenas uma categoria das que serão discutidas abaixo, conforme indicam os procedimentos para análise de conteúdo (Bardin, 1977; Krippendorff, 2004; Lacy et al. 2015)

Os indicadores que viabilizam a classificação a seguir foram construídos a partir de dois marcos, considerados de forma agregada: 1) a reflexão teórica anteriormente explanada, considerandose as variantes conceituais da ideia de "opinião pública"; 2) a pré-análise dos textos, que ajudou a guiar o inventário das tipologias consideradas. Ou seja, para complementar a proposta de indicadores empíricos, os autores, ao reconhecerem que a reflexão teórica não deu conta do fenômeno por completo, debruçaram-se sobre uma amostra de 45 unidades textuais - quase a metade do corpus - a fim de definir as taxonomias mais adequadas ao diagnóstico proposto no trabalho.

A seguir, apresenta-se o detalhamento das categorias que compõem a grade de análise. Os exemplos retirados de trechos dos editoriais que compõem a amostra colaboram para ilustrar o modo como foi realizada a classificação qualitativa.

1. OP Habermasiana: Opinião Pública é forjada a partir de debates e do confronto de ideias apresentadas na esfera pública.

Exemplo: “Assim, o PT e seus associados confirmam sua extraordinária vocação para explorar a chamada 'pós-verdade' na política, fenômeno em que os fatos são considerados irrelevantes para a formação da opinião pública." ("Irresponsáveis por natureza”, 30 nov. 2016).

2. OP Persuasível: Opinião Pública como agente passivo, a ser convencido, por exemplo, por meio da utilização de técnicas de construção de imagem.

Exemplo: “(...) entre outras iniciativas manipuladoras da opinião pública, 'investimentos pesados' em publicidade são capazes de moldar a percepção que as pessoas têm da realidade de acordo com a vontade dos detentores do poder." (A manipulação da comunicação, 19 mar. 2015).

3. OP como agente ativo: Opinião pública como agente ativo que representa a vontade coletiva (ou mesmo se confunde com ela), dotado de vontades, posicionamentos ou demandas. Pode ser apresentada como uma opinião consensual ou como uma opinião da maioria da sociedade.

Exemplo: "Nos últimos dias, acossada por uma opinião pública cada vez mais hostil, Cristina está sendo obrigada a recorrer a todo o seu arsenal de argumentos delirantes para tentar mostrar aos argentinos que nada é o que parece [...]." (Tempos difíceis na Argentina, 19 fev. 2015).

4. OP como agente passivo: Opinião Pública que apenas assiste ou acompanha (sem intervir) os acontecimentos. Também pode ser apresentada como uma opinião consensual ou como uma opinião da maioria da sociedade.

7. Apesar de terem sido encontradas 106 menções ao termo opinião pública nos editoriais, uma delas não foi classificada nas categorias aqui inventariadas, pois se referia ao nome de instituto de pesquisa que atua na área de sondagens. 
Exemplo: "Embora, infelizmente, as chacinas não sejam novidade na periferia da capital e cidades vizinhas - mesmo com a sensível diminuição do índice de homicídios nos últimos anos -, essa última, pelas suas características e dimensões, deixou particularmente chocada a opinião pública." (A chacina de Osasco e Barueri, 18 ago. 2015).

5. OP como resultados de sondagens: Apresentação de índices mensurados por surveys.

Exemplo: "É exatamente diante dessa grave e delicada questão que a última pesquisa de opinião pública CNI/Ibope coloca a consciência democrática do País." (O verdadeiro terceiro turno, 3 abr. 2015)

É possível perceber que alguns dos conceitos de opinião pública apresentados ao longo da seção teórica deste artigo - a exemplo da perspectiva de Lippmann e Dewey ou da noção de opinião pública como "opinião publicada" - não foram mobilizados como categorias empíricas. A bem da verdade, chegou-se a esboçar categorias específicas que contemplassem tais sentidos, mas, uma vez que a pré-análise revelou não haver ocorrência de tais interpretações, decidiu-se desconsiderá-las na montagem dos índices de classificação. Ressalte-se, em tempo, que tal opção analítica não diminui a pertinência teórica das duas abordagens citadas no início deste parágrafo, visto que elas se referem a idealizações singulares para se compreender de forma completa a noção de "opinião pública" no debate contemporâneo.

Definidas as tipologias a serem empregadas no exame empírico, destaca-se a informação de que quatro pesquisadores examinaram, isoladamente, os editoriais com o intuito de mapear a ocorrência, em toda a amostra, das cinco categorias de opinião pública. Realizou-se, em seguida, um teste de confiabilidade a fim de mensurar em que medida os investigadores estavam de acordo quanto à classificação das menções ao termo "opinião pública". A cada divergência diagnosticada entre os classificadores, a menção que gerou discordância foi discutida em conjunto pelos autores deste artigo, seguindo-se estratégias típicas de Análise de Conteúdo elencadas por Lacy et al. (2015). A intenção foi obter consenso sobre qual seria a classificação adequada para cada menção ${ }^{8}$.

\section{Seção de Análise e Discussão}

Nesta seção, serão expostos os resultados da análise empírica, juntamente da discussão sobre os achados que se estabelece em diálogo com a literatura. Elas têm início com a apresentação do gráfico que indica a frequência de distribuição do termo "opinião pública" nos editoriais de OESP ao longo dos anos de 2015 e 2016.

8. O banco de dados, o livro de códigos e o material codificado estão disponíveis sob demanda aos autores. 
Gráfico 1. Frequência de distribuição de editoriais que trazem o termo “opinião pública" em OESP, entre 2015 e 2016 (por mês)

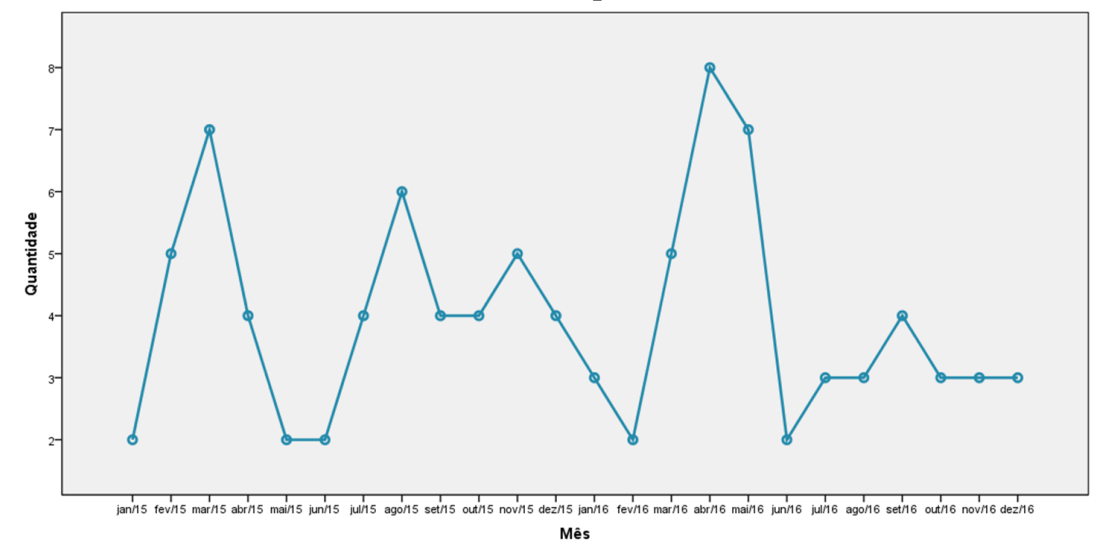

Considerando que há 95 editoriais, ao longo dos 24 meses analisados, tem-se uma média de quase quatro textos $(3,95)$ por mês que trazem o termo opinião pública. Isto corresponde a, aproximadamente, um editorial por semana, indicando que há, com certa regularidade, a mobilização da ideia de opinião pública nos editoriais de OESP. Isto pode ser indício da necessidade do jornal em acionar a opinião pública para respaldar suas demandas em períodos controversos do ponto de vista político.

Os dados apresentados no Gráfico 2 revelam que, na ampla maioria das vezes em que o termo “opinião pública" foi mencionado na amostra, o periódico enfatizou como preocupação central temas relacionados à política (aproximadamente $88 \%$ das peças).

Gráfico 2. Tema geral dos editoriais de OESP que mencionam "opinião pública" (em números absolutos de peças)

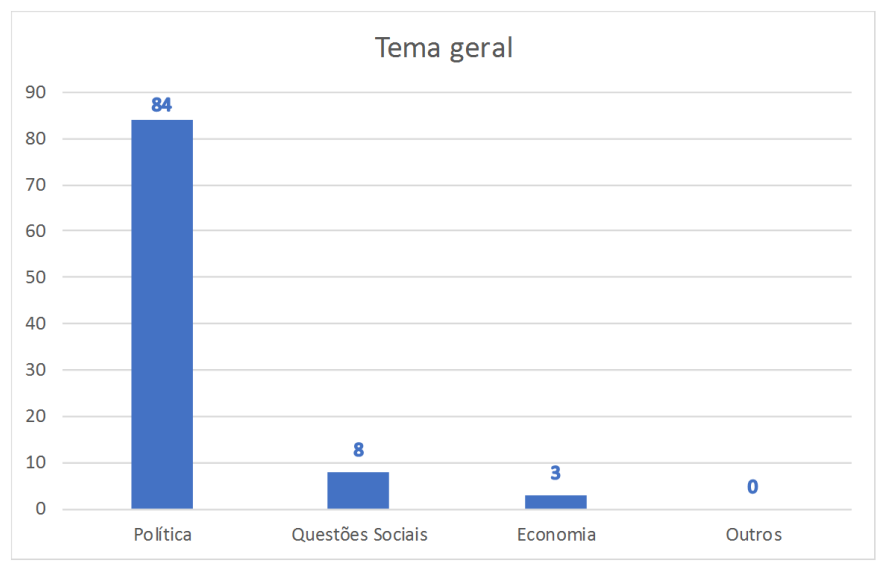


O que significa "Opinião Pública"? Um estudo sobre os diferentes sentidos do termo nos editoriais do jornal O Estado de S. Paulo

Tal postura confirma a hipótese 1 (que sustentava que, por se dirigirem às elites políticas, a maior parte dos editoriais tem Política como tema específico) e se mostra condizente com o que a literatura sobre o tema indica acerca de OESP: trata-se de um periódico que tem o costume de se posicionar de modo enfático acerca dos acontecimentos que envolvem decisões do Executivo, Legislativo e Judiciário (Azevedo, 2016; Capelato e Prado, 1980; Guerreiro Neto, 2016; Sodré, 2009). Deve-se sublinhar que boa parte mesmo daqueles editoriais cuja ênfase se refere a "Questões sociais" ou à "Economia" mencionam lideranças que ocupam cargos no Estado. Por exemplo, ao abordar a violência nos presídios brasileiros, o editorial "O Desafio do crime organizado", de 20 de outubro de 2016 (p. A3), critica a falta de ação do governo federal e dos governos estaduais para combater o crime organizado.

Não são apenas os atos de selvageria, como decapitações e mutilações, que chocam a opinião pública nesses episódios. Mas igualmente a inércia do poder público que, além de assistir à degradação contínua da situação em que se encontram os presos, também não conseguiu até agora nenhum avanço significativo no combate àquelas organizações criminosas. (...) $\mathrm{O}$ desencontro das declarações feitas pelo ministro da Justiça, Alexandre de Moraes, a respeito das rebeliões, ilustra bem a falta de avaliação precisa do que ocorre e, consequentemente, da incapacidade de desenvolver uma ação eficaz contra aqueles grupos. (O Estado de S. Paulo, 20 de outubro de 2016, pp. A3).

Quando se compara tal resultado com aqueles obtidos em outros trabalhos também dedicados ao estudo dos editoriais, percebe-se que, no caso aqui investigado, o tema "Economia" mereceu um destaque menor. No estudo de Mont'Alverne e Marques (2016), quando as palavras-chave a delimitarem a seleção dos editoriais se referiram a "Congresso", "Câmara" ou "Senado", a distribuição de editoriais que tratavam de "Política" e de "Economia" se mostrou mais equilibrada do que ocorreu quando a palavra-chave da busca foi "Opinião Pública". Essa constatação é importante, pois permite verificar a existência de um leque de assuntos (Política, nomeadamente) acerca dos quais o periódico acredita ser importante apresentar as posições ou reações da "opinião pública" - enquanto não as mobiliza quando se trata da pauta econômica.

Considerando-se os Gráficos 1 e 2, é possível refletir sobre em que medida a quantidade significativa das peças a tratarem de política guarda relação com a frequência temporal de acionamento do termo "opinião pública" nos editoriais. Dito de outra forma, ao agregar as informações apresentadas logo acima, abre-se a oportunidade de especular acerca do grau de ocorrência do emprego da expressão "opinião pública" em paralelo a acontecimentos relevantes testemunhados no campo político ao longo dos meses que integram a amostra. Uma vez que o Gráfico 1 aponta que, no ano de 2015, o pico de ocorrências se dá em março, é plausível associar a frequência do termo aqui analisado com os protestos realizados à época contra o governo da então Presidente Dilma Rousseff $^{9}$. O editorial "O não a Dilma persiste", de 14 de abril de 2015 (época em que a repercussão sobre as manifestações de rua ainda se mostrava evidente), traz o seguinte trecho:

Embora as manifestações do último domingo contra a corrupção e a favor do impeachment da presidente Dilma Rousseff tenham demonstrado, como era previsto,

9. Disponível em www1.folha.uol.com.br/especial/2015/protestos-15-de-marco/ e em http://politica.estadao.co m.br/noticias/geral,manifestacoes-contra-dilma-levam-multidao-as-ruas-do-pais,1651418. Acesso em 3 jun. 2017. 
mobilização popular inferior à do evento de 15 de março, 6 em cada 10 brasileiros continuam a repudiar o governo petista e um número maior ainda, $63 \%$, deseja o impeachment da chefe do governo, de acordo com pesquisa Datafolha divulgada no mesmo dia. O teor dessas manifestações de desagrado em relação ao desempenho da presidente, que, como as de março, se estenderam às principais cidades do País, sugere algumas reflexões importantes sobre a crise política [...] $\mathrm{O}$ apoio popular ao impeachment de Dilma Rousseff existe, por ampla maioria, como comprovam as pesquisas de opinião pública. (O Estado de S. Paulo, 14 de abril de 2015, pp. A3).

Em 2016, a maior quantidade de ocorrências do termo "opinião pública" em editoriais - que corresponde, aliás, ao pico quando se consideram os dois anos em conjunto - se dá em abril, justamente quando o processo de impeachment de Dilma foi aprovado pelo plenário da Câmara dos Deputados. Segue trecho de editorial publicado à época por OESP.

Não contente em tentar enganar a opinião pública nacional, especialmente no que diz respeito à legalidade do processo de impeachment, por ela qualificado de "golpe", Dilma dedica-se agora a espalhar sua farsa mundo afora, conforme se verifica na impressionante entrevista que concedeu à imprensa estrangeira há uma semana. ( $\mathrm{O}$ Estado de S. Paulo, 26 de Abril de 2016, pp. A3).

Chama a atenção o fato de que, nos meses seguintes - não obstante também registrado intensa "movimentação" do ponto de vista político -, percebe-se uma queda significativa na quantidade de editoriais que mencionam o termo "opinião pública". Isso ocorre mesmo no mês de agosto de 2016, quando o Plenário do Senado Federal aprovou o afastamento definitivo da então Presidente. Essa postura pode indicar que a opinião pública foi mobilizada apenas em momentos anteriores à divulgação dos resultados do processo (ou seja, uma vez que, no Senado, a aprovação do impedimento de Dilma parecia mais certa do que se projetava na Câmara, OESP não teve a mesma preocupação em enfatizar o papel da opinião pública no referido processo político).

Um dos dados mais interessantes dentre aqueles revelados pelo levantamento se refere ao sentido de opinião pública acionado pelos editoriais. A partir deste ponto, a unidade de análise passa a ser a quantidade de menções ao termo opinião pública, conforme explicado na seção metodológica.

Conforme aponta o gráfico 3, é clara a opção de OESP em atribuir à ideia de opinião pública um papel de agente ativo, dotado de demandas e, nesse sentido, com capacidade e legitimidade para pressionar os agentes do Estado. Das 105 menções ao termo, pelo menos 44 (aproximadamente $42 \%$ das ocorrências) consideram que a opinião pública se manifesta, critica ou avalia atitudes e agentes sociais, políticos e econômicos diversos. 
O que significa "Opinião Pública"? Um estudo sobre os diferentes sentidos do termo nos editoriais do jornal O Estado de S. Paulo

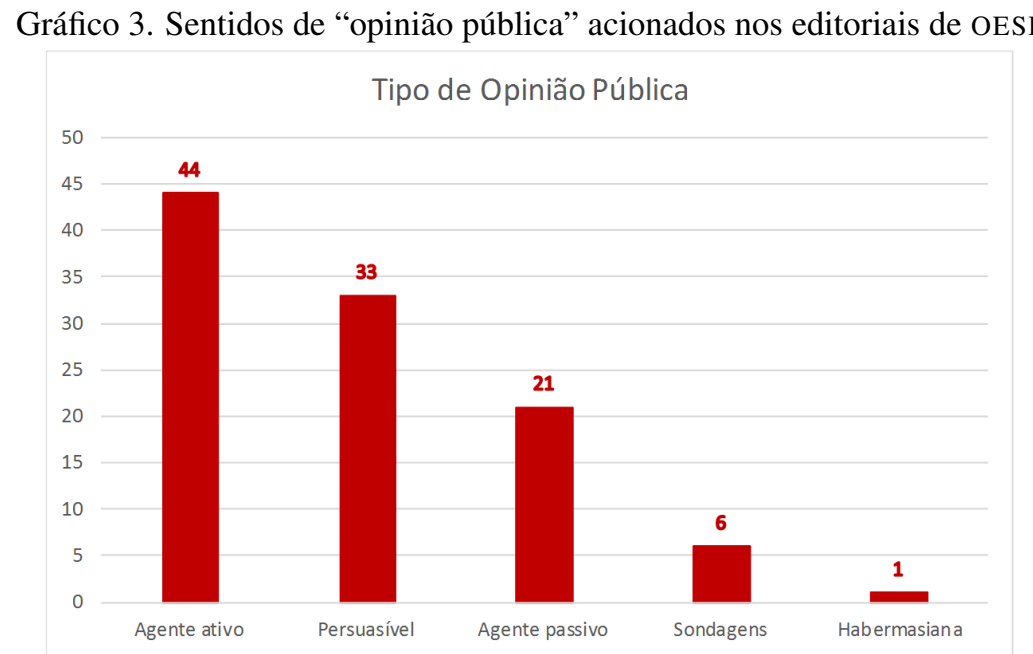

Aqui deve ser observado que a predominância da ideia de opinião pública como agente ativo abre a possibilidade de que o uso do termo acabe servindo para apresentar, como se fossem de interesse geral, demandas que, na verdade, são da própria empresa jornalística. É o que se evidencia a partir do trecho abaixo:

Renan Calheiros, portanto, terá um papel importante a cumprir nesse processo, e a opinião pública, cada vez mais impaciente com os políticos em geral, estará de olho em seu comportamento. Está aí um argumento que um político experiente como o senador alagoano certamente não deixará de levar em conta em suas decisões. (O Estado de S. Paulo, 09 de outubro de 2015, pp. A3).

Ao defender que a opinião pública "está impaciente", OESP tem a oportunidade de ocultar (pelo menos parcialmente) seu papel de instituição interessada na adoção de determinadas políticas ou diretrizes - além de transferir a fonte de suas próprias demandas para outrem, como se tudo o que o editorial apresentasse fosse reivindicação da sociedade. A impaciência, na realidade, pertence a setores da sociedade, do campo econômico e ao próprio jornal. No entanto, o interesse apresenta-se de forma mais legítima se for atribuída à sociedade como um todo. Em suma, argumenta-se que, no caso, há uma instrumentalização da ideia de "opinião pública" a fim de que ela sirva de arma de convencimento junto aos demais atores sociais.

Em segundo lugar, encontra-se o sentido de "opinião pública" como instância a ser persuadida: a ideia de que diferentes agentes (desde presidentes a ministros, passando por instituições de vários campos sociais) precisam se esforçar para convencer a opinião pública de que algo é positivo ou negativo está presente em 33 menções (aproximadamente 31\%). É o que se vê no excerto a seguir:

(...) ao focalizar como o grande tema do início do seu segundo mandato a 'batalha da comunicação', a presidente mostra que, para ela, governar é envolver-se em picuinhas. Já não se trataria de administrar bem os recursos públicos, prover serviços públicos adequados, corrigir o que está indo mal. O que lhe parece importar é construir uma 
imagem favorável perante a opinião pública. (O Estado de S. Paulo, 31 de jan de 2015, pp A3).

Ao mesmo tempo, também há significativa preocupação, por parte dos editoriais, com as tentativas do campo político em "manipular" a opinião pública. Curiosamente, os editoriais de OESP não apontam o próprio jornal (ou instituições congêneres do campo midiático) como agentes capazes de influenciar a opinião pública. Isto é, a tarefa de convencimento acerca das posições socialmente defensáveis ficaria sob responsabilidade de agentes externos ao Jornalismo, o que revela um paradoxo com a função específica do editorial de orientar o leitor, conforme identifica a literatura. Ainda assim, atribuir a tentativa de "manipular" a opinião pública ao campo político é uma estratégia que condiz com o posicionamento do Jornalismo como adversário da política. A partir desta perspectiva, caberia ao campo jornalístico a função de atuar como uma espécie de ombudsman da audiência, apontando agendas escondidas e reais motivos para as ações dos agentes políticos, enquanto fortalece sua própria legitimidade (Clayman, 2002; Eriksson, 2011; Eriksson e Ostman, 2013; Van Dalen, Albæk e De Vreese, 2011).

Já a ideia de opinião pública como agente que meramente assiste ou acompanha os acontecimentos está presente em 21 das menções encontradas na amostra (o que corresponde a 20\%). Nestes momentos, a opinião pública aparece como frágil, ou seja, como instância que precisaria ser tutelada. É neste espaço que o periódico reforça seu papel como guardião da audiência - em contraponto ao campo político, reforçando um papel adversário em relação aos agentes representativos do Estado. Em outras palavras, a função de watchdog reclamada pelo jornal é reforçada pela compreensão de opinião pública como agente passivo, que assiste aos acontecimentos. Há o espaço, portanto, para OESP reforçar seu papel como representante do leitor, mantendo uma relação de tensão com o campo político (Azevedo e Chaia, 2008; Van Aelst et al., 2008; Waisbord, 2000, 2015).

A compreensão de opinião pública como resultado de sondagens (6\%) ou como o resultado dos debates que têm lugar na esfera pública (1\%) é bem menos acionada do que os outros sentidos. É importante ressaltar, portanto, que os editoriais de OESP, frequentemente, falam em opinião pública como uma vontade coletiva, mas sem utilizar pesquisas de opinião que legitimem essa ideia - apenas três dos editoriais mobilizando o sentido de opinião pública como agente ativo trazem resultados de sondagens para sustentá-la. Ou seja, o jornal apresenta qual seria a opinião pública socialmente compartilhada, mas sem se preocupar em tornar evidente se, de fato, trata-se da vontade de parte mais numerosa dos cidadãos (não obstante as limitações já debatidas, na seção teórica, de tomar resultados de sondagens de opinião como indicadores totalmente acurados do clima de opinião). O periódico apresenta-se, deste modo, como portador das demandas da opinião pública.

Ao mesmo tempo, nenhuma das 105 menções à opinião pública no intervalo de 24 meses trouxe o sentido de "opinião publicada". Em outras palavras, OESP não se referiu à "opinião pública" como aquele tipo de opinião "publicada" que circulou em diferentes produtos da cultura midiática, sejam tais conteúdos elaborados ou não pela empresa jornalística em questão. Uma explicação para isso reside no fato de que o próprio editorial ressalta seu papel de portador da opinião e de representante do interesse público. 

de S. Paulo

O Gráfico 4, por sua vez, dispõe a frequência temporal dos sentidos de "opinião pública" que são acionados nos editoriais de OESP. Com vistas a facilitar a visualização da distribuição dos sentidos mais recorrentes de "opinião pública" nas peças examinadas, apenas aquelas categorias que obtiveram pelo menos 10 ocorrências (dentre as 105 inventariadas) são consideradas no gráfico - a saber, "Agente ativo", "Persuasível" e "Agente passivo".

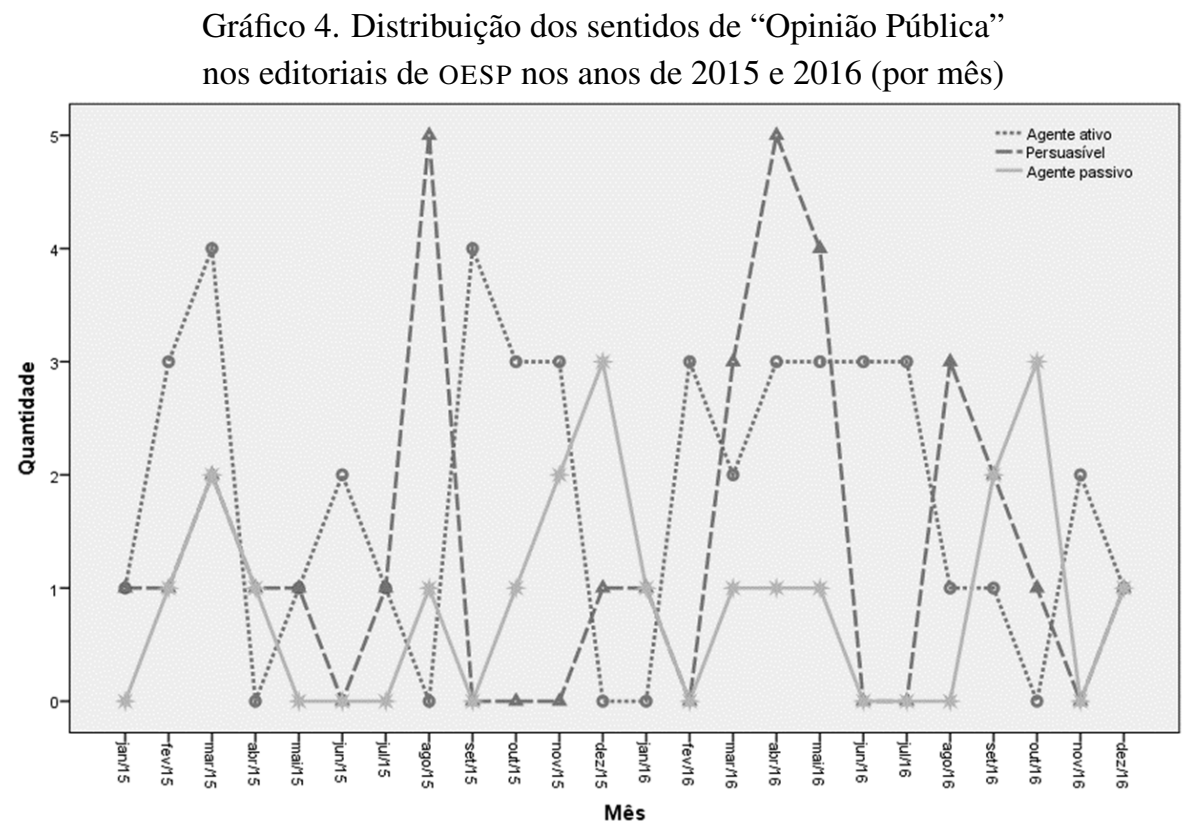

É possível constatar que os picos correspondentes a cada um dos sentidos ocorrem em momentos distintos. Os auges da ideia de opinião pública como "agente ativo" nos editoriais que integram a amostra se dão em março e em setembro de 2015, enquanto, no caso de "opinião pública como agente passivo", os picos ocorrem em dezembro de 2015 e em outubro de 2016. No caso de "opinião pública persuasível", o primeiro pico se dá agosto de 2015 , enquanto o segundo acontece em abril de 2016.

Percebe-se, considerados os sentidos de opinião pública como "agente passivo" e como "agente ativo", que o crescimento de ocorrências de um está alinhado com a queda de outro no mesmo período. Já a curva de opinião pública "persuasível" não aparenta estar relacionada às outras interpretações no que concerne à quantidade de ocorrências.

Os dados apresentados, então, apontam para a confirmação da hipótese 2, tendo-se constatado que a ideia mais recorrente de "opinião pública" apresentada nos editoriais refere-se ao sentido do termo enquanto agente ativo e capaz de representar a vontade coletiva. Ainda que haja espaço para outros sentidos, este é o que predomina ao longo do material examinado, indicando que OESP percebe a opinião pública como uma instituição autônoma e vigilante em relação às movimentações do campo político e de seus agentes. 


\section{Para Concluir}

O artigo propôs, em um primeiro momento, reconhecer e atualizar a literatura relacionada ao conceito de opinião pública, tendo em conta a multiplicidade de abordagens que o tema comporta. Além disso, a seção empírica examinou de que forma os editoriais do jornal $O$ Estado de $S$. Paulo mobilizam a ideia de opinião pública. O objetivo da dimensão analítica foi verificar a possível instrumentalização de tal noção com finalidades políticas por parte do periódico em tela.

Os resultados apontam que os editoriais de OESP mobilizam, com maior frequência, a ideia de opinião pública como um agente ativo, ao mesmo tempo que o jornal demonstra preocupação com a possibilidade de que a opinião pública pudesse ser persuadida por meio de estratégias mobilizadas por agentes do campo político. Assim, a estratégia do periódico se configura como, em certos momentos, apresentar a opinião pública como agente autônomo e portador de demandas e posicionamentos - os quais a empresa jornalística se sente autorizada a traduzir e expressar. Em outros instantes, OESP resguarda seu papel como cão-de-guarda do leitor, ao apontar como e com qual finalidade os agentes políticos procuram persuadi-la. Para isso, o jornal acredita na estratégia de evidenciar quais seriam os "reais" interesses a mover tais agentes.

Ou seja, em alguns editoriais, a opinião pública é tratada como ser inanimado que possui autoridade e legitimação. Em outras peças, é tomada na condição de ente frágil, facilmente manipulável ou controlável - e, justamente por isso, precisaria ser tutelado pela interpretação oferecida pelo jornal. A depender da conveniência para o periódico, portanto, a opinião pública precisa ou não ser protegida, um papel que OESP se propõe a desempenhar.

Como agenda de pesquisa, pretende-se investir em estudos de caso comparativos a fim de se investigar em que medida periódicos distintos mobilizam a ideia de opinião pública. Tal medida possibilitará perceber os graus de instrumentalização nos usos do referido termo.

\section{Referências}

Almeida, J. (1999). Mídia, opinião pública ativa e esfera pública democrática. Comunicação \& Política, 6 (1). Rio de Janeiro.

Arnold, R. D. (2004). Congress, the press, and political accountability. Princeton: Princeton University Press.

Albright, S. (1995) Opinion readership scores higher than common wisdom predicts. The Masthead, 47 (1), 5.

Azevedo, F. (2016). A grande imprensa brasileira: paralelismo político e antipetismo (19892014). Tese de Doutorado, Universidade Federal de São Carlos, São Carlos.

Azevedo, F. \& Chaia, V. (2008). O Senado nos editoriais dos jornais paulistas (2003-2004). Opinião Pública, 14 (1): 173-204.

Bardin, L. (1977). Análise de conteúdo. Lisboa: Edições.

Bauer, M. W. (2002). Análise de conteúdo clássica: uma revisão. In M. W. Bauer \& G. Gaskell (eds.). Pesquisa qualitativa com texto, imagem e som: um manual prático (189-217). Rio de Janeiro: Vozes. 
O que significa "Opinião Pública"? Um estudo sobre os diferentes sentidos do termo nos editoriais do jornal O Estado de S. Paulo

Beltrão, L. (1980). Jornalismo opinativo. Porto Alegre: Sulina.

Bennett, W. L.; Lawrence, R. G. \& Livingston, S. (2007). When the press fails: political power and the news media from Iraq to Katrina. Chicago: University of Chicago Press.

Blumenthal, S. (1982). The permanent campaign. New York: Simon and Schuster.

Bourdieu, P. (1980). A opinião pública não existe. In M. Thiollente, Crítica metodológica, investigação social e enquete operária, (137-51). São Paulo: Polis.

Campos, L. A. (2015). Imprensa e esfera pública: retomando o debate Lippmann-Dewey sobre o papel público da imprensa. Compós. Brasília.

Capelato, M. H. \& Prado, M. L. (1980). O bravo matutino: imprensa e ideologia no jornal $O$ Estado de S. Paulo. São Paulo: Alfa-Ômega.

Cavalcante, R. B.; Calixto, P. \& Pinheiro, M. M. K. (2014). Análise de conteúdo: Considerações gerais, relações com a pergunta de pesquisa, possibilidades e limitações do método. Informacao e Sociedade, 24 (1): 13-18.

Champagne, P. (1996). Formar a opinião: o novo jogo político. Petrópolis: Vozes.

Cervi, E. U. (2006). Opinião pública e política no Brasil. Tese de Doutorado, Instituto Universitário de Pesquisas do Rio de Janeiro, Rio de Janeiro.

Clayman, S. E. (2002). Tribune of the people: maintaining the legitimacy of aggressive journalism. Media, Culture \& Society, 24 (2): 197-216.

Cook, T. E. (2005). Governing with the news. Chicago: The University of Chicago Press.

Correia, J. C. (2010). Ideologia, crítica e deliberação. In J. C. Correia, G. B. Ferreira \& P. Espirito Santo (orgs.), Conceitos de Comunicação Política (pp. 09-20). Covillhã: LabCom Books.

Dewey, J. (1927). The public and its problems. Henry Holt and Company.

Donsbach, W. (2015). Public opinion polls. In G. Mazzoleni (ed.), The International Encyclopedia of Political Communication (pp. 01-11). John Wiley \& Sons.

Eberwein, T.; Porlezza, C. \& Splendore, S. (2015). Media as political actors. In G. Mazzoleni (ed.), The international encyclopedia of political communication (pp. 01-09). John Wiley \& Sons.

Entman, R. M. (2007). Framing Bias: Media in the Distribution of Power. Journal of Communication, 57 (1): 163-173.

Eriksson, G. (2011). Adversarial moments: a study of short-form interviews in the news. Journalism, 12 (1): 51-69.

Eriksson, G. \& Ostman, J. (2013). Cooperative or Adversarial? Journalists' Enactment of the Watchdog Function in Political News Production. The International Journal of Press/Politics, 18 (3): 304-324.

Esteves, J. P. (2010). Opinião Pública. In J. C. Correia, G. B. Ferreira \& P. Do E. Santo (eds.), Conceitos de Comunicação Política (pp. 21-32). Covilhã: LabCom Books. 
Fallows, J. (1997). Detonando a notícia: como a mídia corrói a democracia americana. Rio de Janeiro: Civilização Brasileira.

Gomes, W. (2001). Opinião pública política hoje: ujma investigação preliminar. In: A. Hohlfeldt (ed.), Práticas mediáticas e espaço público (pp. 61-82). Porto Alegre: Editora da PUC/RS.

Gomes, W. (2004). Transformações da política na era da comunicação de massa. São Paulo: Paulus.

Glasser, T. L. \& Salmon, C. T. (eds.) (1995). Public opinion and the communication of consent. New York: Guilford.

Graber, D. (2003). The media and democracy: Beyond myths and stereotypes. Annual Review of Political Science, 6: 139-160.

Grossi, G. (2007). La opinion publica. Madrid: Centro de Investigaciones Sociológicas.

Guerreiro Neto, G. (2016). Da opinião à identidade: características do editorial em dois jornais brasileiros. Sobre Jornalismo, 5 (2): 92-105.

Habermas, J. (1984). Mudança estrutural da esfera pública. Rio de Janeiro: Tempo Brasileiro.

Hacker, K. L. (2004). Presidential candidate images. Oxford: Rowman \& Littlefield Publishers.

Hahn, K. S.; Lee, H.-Y. \& Lee, J. (2015). Media Bias. In G. Mazzoleni (ed.), The international encyclopedia of political communication (pp. 01-09). John Wiley \& Sons.

Hallock, S. M. (2007). Editorial and opinion. Praeger: Westport.

Ho, S. S. (2015). Spiral of silence. In G. Mazzoleni (ed.), The international encyclopedia of political communication (pp. 01-05). John Wiley \& Sons.

Holtz-Bacha, C. (2015). Professionalization. In G. Mazzoleni (ed.). The international encyclopedia of political communication (pp. 01-07). John Wiley \& Sons.

Izadi, F. \& Saghaye-Biria, H. (2007). A discourse analysis of elite American newspaper editorials: The case of Iran's nuclear program. Journal of Communication Inquiry, 31 (2): 140-165.

Kahn, K. F. \& Kenney, P. J. (2002). The slant of the news: how editorial endorsements influence campaign coverage and citizens views of candidates. American Political Science Review, 96 (2): 381-394.

Krippendorff, K. (2004). Content analysis: an introduction to its methodology. London: Sage Publications.

Kovach, B. \& Rosenstiel, T. (2004). Os elementos do jornalismo. São Paulo: Geração Editorial.

Lacy, S. et al. (2015). Issues and best practices in content analysis. Journalism \& Mass Communication Quarterly, 92 (4): 791-811.

Lippman, W. (2008). Opinião pública. Petrópolis: Vozes.

Maia, R. (2008). Deliberação e mídia. In R. C. M. Maia (ed.), Mídia e deliberação (pp. 93-110). Rio de Janeiro: Editora FGV.

Manin, B. (1995). As metamorfoses do governo representativo. Revista Brasileira de Ciências Sociais, 10 (29): 5-34. 
O que significa "Opinião Pública"? Um estudo sobre os diferentes sentidos do termo nos editoriais do jornal O Estado de S. Paulo

Marques, F. P. J. A. (2010). Participação política, legitimidade e eficácia democrática. Caderno CRH, 23: 591-604.

Matteucci, N. (1983). Opinião pública. In N. Bobbio, N. Matteucci \& G. Pasquino, Dicionário de politica (pp. 842-845). Brasília: Editora UnB.

McCombs, M. E. \& Shaw, D. L. (1972). The agenda- setting function of mass media. Public Opinion Quarterly, 36 (2): 176-187.

Miguel, L. F. (2014). Democracia e representação: territórios em disputa. São Paulo: Editora Unesp.

Miola, E. (2012). Sistema deliberativo e tensões entre interesses públicos e privados: a criação da empresa Brasil de comunicação em debate no congresso e na imprensa. Tese de Doutorado, Universidade Federal de Minas Gerais, Faculdade de Filosofia e Ciências, Belo Horizonte.

Mont'Alverne, C. \& Marques, F. P. J. A. (2015). A opinião da empresa no Jornalismo brasileiro: um estudo sobre a função e a influência política dos editoriais. Estudos em Jornalismo e Mídia, 12 (1): 121-137.

Mont'Alverne, C. \& Marques, F. P. J. A. (2016). Pauta do dia: um estudo sobre o agendamento do congresso nacional brasileiro nos editoriais da Folha de S. Paulo e de O Estado de S. Paulo. Brazilian Journalism Research, 12 (2): 120-147.

Negrine, R. (2015). Americanization. In G. Mazzoleni (ed.), The international encyclopedia of political communication (pp. 01-05). John Wiley \& Sons.

Noelle-Neumann, E. (1995). La espiral del silencio. Barcelona: Paidós.

Noelle-Neumann, E. \& Petersen, T. (2004). The spiral of silence and the social nature of man. In L. L. Kaid (ed.), Handbook of political communication research (pp. 339-356). London: Lawrence Erlbaum Associates.

Nunes, M. C. (2002). O papel das pesquisas. In R. Figueiredo (org), Marketing político e persuasão eleitoral (pp. 43-65). Rio de Janeiro: K. A. Stiftung.

O Estado de S. Paulo, O. (1997). Manual de redação e estilo de O Estado de S. Paulo. São Paulo.

Richards Jr, R. C. \& Gastil, J. (2015). Deliberation. In G. Mazzoleni (ed.), The international encyclopedia of political communication (pp. 01-13). John Wiley \& Sons.

Rupar, V. (2007). Newspapers' production of common sense: The "greenie madness" or why should we read editorials?. Journalism, 8 (5): 591-610.

Schudson, M. (2008). Why democracies need an unlovable press. Cambridge: Polity Press.

Schoenbach, K. \& Becker, L. (1995). Origins and consequences of mediated public opinion. In T. L. Glasser \& T. Salmon, Public opinion and the communication of consent (pp. 323-347). New York: Guilford Press.

Sodré, M. (2009). A narração do fato: notas para uma teoria do acontecimento. Petrópolis: Vozes.

Sodré, N. W. (1999). História da imprensa no Brasil. Rio de Janeiro: Mauad. 
Sproule, J. M. (2015). Propaganda. In G. Mazzoleni (ed.), The international encyclopedia of political communication (pp. 01-09). John Wiley \& Sons.

Thurber, J. A. \& Ray, A. D. (2015). Consultant, political. In G. Mazzoleni (ed.), The international encyclopedia of political communication (pp. 01-04). John Wiley \& Sons.

Van Aelst, P. et al. (2008). The fourth estate as superpower?. Journalism Studies, 9 (4): 494-511.

Van Dalen, A. (2015). Journalism, Political. In G. Mazzoleni (ed.), The international encyclopedia of political communication (pp. 01-10). John Wiley \& Sons.

Van Dalen, A.; Albæk, E. \& De Vreese, C. (2011). Suspicious minds: explaining political cynicism among political journalists in Europe. European Journal of Communication, 26 (2): 147-162.

Waisbord, S. (2000). Watchdog journalism in South America: news, accountability, and democracy. Columbia: Columbia University Press.

Waisbord, S. (2015). Watchdog journalism. In G. Mazzoleni (ed.), The international encyclopedia of political communication (pp. 01-05). John Wiley \& Sons.

Weber, M. H. (2004). Imagem pública. In A. Rubim (ed.), Comunicação e política: conceitos e abordagens (pp. 259-307). Salvador: Edufba.

Weber, M. H. (2009). O estatuto da imagem pública na disputa política. ECO-Pós, 12 (3): 11-26. 